\title{
Evaluation of heat stress effects on production traits and somatic cell score of Holsteins in a temperate environment
}

\author{
H. Hammami, ${ }^{1} \dagger^{1}$ J. Bormann, $\ddagger$ N. M’hamdi, $§$ H. H. Montaldo,\# and N. Gengler ${ }^{\star}$ \\ *Animal Science Unit, Gembloux Agro-Bio Tech, University of Liège, B-5030 Gembloux, Belgium \\ †National Fund for Scientific Research, B-1000 Brussels, Belgium \\ $\ddagger$ Administration of Agricultural Technical Services, L-1019 Luxembourg, Luxembourg \\ §Animal Science Department, High Institute of Agronomy of Chott-Mariem, TN-4042 Sousse, Tunisia \\ \#Departamento de Genética y Bioestadística, Facultad de Medicina Veterinaria y Zootecnia, Universidad Nacional Autónoma de México, \\ Ciudad Universitaria, D.F. 04510, Mexico
}

\begin{abstract}
This study was aimed to evaluate the degree of thermal stress exhibited by Holsteins under a continental temperate climate. Milk, fat, protein, and somatic cell count test-day records collected between 2000 and 2011 from 23,963 cows in 604 herds were combined with meteorological data from 14 public weather stations in Luxembourg. Daily values of 6 different thermal indices (TI) weighted in term of temperature, relative humidity, solar radiation, and wind speed were calculated by averaging hourly TI over $24 \mathrm{~h}$. Heat stress thresholds were first identified by a broken-line regression model. Regression models were thereafter applied to quantify milk production losses due to heat stress. The tipping points at which milk and protein yields declined were effectively identified. For fat yield, no valid threshold was identified for any of the studied TI. Daily fat yields tended to decrease steadily with increasing values of TI. Daily somatic cell score patterns were marked by increased values at both lowest and highest TI ranges, with a more pronounced reaction to cold stress for apparent temperature indices. Thresholds differed between TI and traits. For production traits, they ranged from $62\left(\mathrm{TI}_{1}\right)$ to $80\left(\mathrm{TI}_{3}\right)$ for temperature-humidity indices (THI) and from $16\left(\mathrm{TI}_{5}\right)$ to $20\left(\mathrm{TI}_{6}\right)$ for apparent temperature indices. Corresponding somatic cell score thresholds were higher and ranged from $66\left(\mathrm{TI}_{1}\right)$ to 82 $\left(\mathrm{TI}_{3}\right)$ and from $20\left(\mathrm{TI}_{5}\right)$ to $23\left(\mathrm{TI}_{6}\right)$, respectively. The largest milk decline per unit of mild, moderate, and extreme heat stress levels of $0.164,0.356$, and $0.955 \mathrm{~kg}$, respectively, was observed when using the conventional THI $\left(\mathrm{TI}_{1}\right)$. The highest yearly milk, fat, and protein losses of $54,5.7$, and $4.2 \mathrm{~kg}$, respectively, were detected by $\mathrm{TI}_{2}$, the THI index that is adjusted for wind speed and solar radiation. The latter index could be consid-
\end{abstract}

Received July 16, 2012.

Accepted November 11, 2012.

${ }^{1}$ Corresponding author: hedi.hammami@ulg.ac.be ered as the best indicator of heat stress to be used for forecast and herd management in a first step in temperate regions under anticipated climate changes.

Key words: thermal index, heat stress, temperate climate, dairy cattle

\section{INTRODUCTION}

Climate change is expected to have an impact on animal production throughout the world (IPCC, 2007). Climate extremes are more likely, exposing previously temperate regions to sustained hot periods. Under temperature, relative humidity $(\mathbf{R H})$, solar radiation (RAD), and wind speed (WS) that exceed their thermal comfort zone, dairy cows suffer from heat stress. Heat stress reduces milk production, reproductive performance, and profit (St-Pierre et al., 2003; Bohmanova et al., 2007; Boonkum et al., 2011).

Temperature-humidity index (THI), which uses dry bulb temperature $\left(\mathbf{T}_{\mathrm{db}}\right)$ and wet bulb temperature, was initially developed by Thom (1959) as a heat index for human comfort but it remained the most common heat stress indicator used until now for different animal species. Various THI more adapted to cattle comfort were later developed (Bianca, 1962; Berry et al., 1964; NRC, 1971). Most of those indices were evaluated as potential predictors of heat stress and milk yield losses of dairy cattle using large data sets in humid and hot tropical environments (Bohmanova et al., 2007; Dikmen and Hansen, 2009). The THI is still the most widespread indicator of heat stress; however, it has its limitations because it is (1) an empirical representation, (2) assumes that all animals react similarly to environmental stressors, and (3) does not account for other environmental effects (e.g., WS and RAD) and cow-specific effects (e.g., age and breed). Recently, technological advances have facilitated the collection of large and precise additional environmental parameters (e.g., RAD, WS, and duration of exposure) and physiological parameters (e.g., respiration rate, rectal and core body 
temperature, and sweating rate). New thermal indices (TI) that incorporated those environmental and physiological data in addition to cow specificities (e.g., breed and age) have been developed to overcome the various THI limitations (Mader et al., 2006; Gaughan et al., 2008; Mader et al., 2010).

Comprehensive scientific studies related to heat stress in dairy cattle were exclusively conducted in the United States using large local performance and weather data (Bohmanova et al., 2007; Aguilar et al., 2009; Sánchez et al., 2009) and also similar data from tropical regions (Boonkum et al., 2011). Even if differences in thresholds of heat stress for different combination of regions and THI indices (Bohmanova et al., 2007) were found, the THI (NRC, 1971) was extensively used to estimate the thresholds of heat stress. A THI value of 72 , which corresponds to $22^{\circ} \mathrm{C}$ at $100 \%$ humidity, has been continuously applied as a reference for genetic evaluation of heat tolerance in US Holsteins for daily milk (Bohmanova et al., 2005; Aguilar et al., 2010). Adjusted THI and new TI incorporating RAD and WS were not evaluated, probably due to unavailable data for the later parameters, but mainly because cows in the United States are generally housed under shade structures during periods of heat stress or may even benefit from cooling systems.

Studies on heat stress effects in temperate regions and especially in Europe are scarce. The few studies focused on evaluating heat stress in dairy cattle (Broucek et al., 2007; Reiczigel et al., 2009; Gantner et al., 2011) pointed out an increase in heat stress days for the past $30 \mathrm{yr}$, with an extreme hot summer in 2003. In 2003 alone, more than $80 \mathrm{~d}$ exceeded the THI of 72 in Eastern Europe. Nevertheless, these studies were based on limited data sets and arbitrarily used the THI value of 72 as the threshold of heat stress onset. Recently, a study using data from Germany observed a decline in protein yield in Holstein dairy cattle from a THI of 60 (Brügemann et al., 2011). The authors reported that this low threshold was associated with a decline in protein yield at phenotypic level and a decrease in genetic variances and heritabilities.

Under expected climate change, evaluation of heat stress relief and knowledge of possible genotype by environment interactions is of increasing interest. Selection for heat tolerance in Holsteins based on THI in genetic evaluation is, therefore, possible also in temperate regions (Brügemann et al., 2011) and could be a sustainable strategy to supplement feed or housing modifications. Nevertheless, knowledge of heat stress thresholds is first needed. Thermal indices and their appropriate thresholds are not fixed features for any population and they may change with the ability of animals to adapt to environmental conditions. To our knowledge, no study has focused on evaluating heat stress effects based on large field data and using either old or new TI that included WS and RAD in addition to $T_{d b}$ and RH. The main objective of this study was to assess the effect of heat stress on production traits and SCS of Holsteins bred under temperate climate conditions using the most comprehensive thermal comfort indices.

\section{MATERIALS AND METHODS}

\section{Data}

A total of 230,192 first-lactation test-day records for milk, fat, and protein yields and SCC from 23,963 Holstein cows collected between 2000 and 2011 in 604 herds by CONVIS Herdbuch, Service Elevage et Génétique (Ettelbruck, Luxembourg) and provided by United Datasystems for Animal Production [Vereinigte Informationssyteme Tierhaltung (VIT), Verden, Germany] were used in this study. Only records from cows with DIM between 5 and 330 were retained. Cows were required to have at least 5 records. Somatic cell score was calculated according to the formula SCS $=\log _{2}$ $(\mathrm{SCC} / 100)+3$.

Hourly meteorological data $\left(\mathrm{T}_{\mathrm{db}}, \mathrm{RH}, \mathrm{WS}, \mathrm{RAD}\right.$, and rain) collected between 2000 and 2011 in 14 public stations in Luxembourg, were provided by Administration des services techniques de l'agriculture (ASTA, Luxembourg). Six TI were calculated using $\mathrm{T}_{\mathrm{db}}\left({ }^{\circ} \mathrm{C}\right), \mathrm{RH}(\%)$, WS $(\mathrm{m} / \mathrm{s})$, and $\operatorname{RAD}\left(\mathrm{W} / \mathrm{m}^{2}\right)$ as follows:

$\mathrm{TI}_{1}$ : temperature-humidity index $(\mathrm{NRC}, 1971)$ :

$$
\begin{aligned}
\mathrm{THI}=(1.8 \times & \left.\mathrm{T}_{\mathrm{db}}+32\right)-[(0.55-0.0055 \times \mathrm{RH}) \\
& \left.\times\left(1.8 \times \mathrm{T}_{\mathrm{db}}-26\right)\right] ;
\end{aligned}
$$

$\mathrm{TI}_{2}$ : adjusted THI ( $\mathrm{THI}_{\text {adj }}$; Mader et al., 2006):

$$
\begin{aligned}
\mathrm{THI}_{\text {adj }}= & {[4.51+\mathrm{THI}-(1.992 \times \mathrm{WS})} \\
& +(0.0068 \times \mathrm{RAD})],
\end{aligned}
$$

where

$$
\mathrm{THI}=\left(0.8 \times \mathrm{T}_{\mathrm{db}}\right)+\left[\mathrm{RH} \times\left(\mathrm{T}_{\mathrm{db}}-14.4\right)\right]+46.4 ;
$$

$\mathrm{TI}_{3}$ : heat load index (HLI; Gaughan et al., 2008):

$$
\begin{gathered}
\text { HLI }=8.62+(0.38 \times \mathrm{RH})+(1.55 \times \mathrm{BG}) \\
-(0.5 \times \mathrm{WS})+\mathrm{e}^{(2.4-\mathrm{WS})}, \text { when } \mathrm{BG}>25 ; \\
\text { HLI }=10.66+(0.28 \times \mathrm{RH})+(1.3 \times \mathrm{BG}) \\
- \text { WS }, \text { when } \mathrm{BG} \leq 25,
\end{gathered}
$$


where

$$
\begin{gathered}
\mathrm{BG}=\left(1.33 \times \mathrm{T}_{\mathrm{db}}\right)-\left(2.65 \times \mathrm{T}_{\mathrm{db}}^{0.5}\right) \\
+[3.21 \times \log (\mathrm{WS}+1)]+3.5
\end{gathered}
$$

is the predicted globe temperature $\left({ }^{\circ} \mathrm{C}\right)$;

$\mathrm{TI}_{4}$ : equivalent temperature index (ETI; Baeta et al., 1987):

$$
\begin{gathered}
\mathrm{ETI}=27.88-\left(0.45 \times \mathrm{T}_{\mathrm{db}}\right)+\left(0.010754 \times \mathrm{T}_{\mathrm{db}}{ }^{2}\right) \\
-(0.4905 \times \mathrm{RH})+\left(0.00088 \times \mathrm{RH}^{2}\right)+(1.1507 \\
\times \mathrm{WS})-\left(0.12644 \times \mathrm{WS}^{2}\right)+[0.019876 \\
\left.\times\left(\mathrm{T}_{\mathrm{db}} \times \mathrm{RH}\right)\right]-\left[0.04631 \times\left(\mathrm{T}_{\mathrm{db}} \times \mathrm{WS}\right)\right] ;
\end{gathered}
$$

$\mathrm{TI}_{5}$ : environmental stress index (ESI; Moran et al., 2001):

$$
\begin{gathered}
\mathrm{ESI}=\left(0.63 \times \mathrm{T}_{\mathrm{db}}\right)-(0.03 \times \mathrm{RH}) \\
+(0.02 \times \mathrm{RAD})+\left[0.0045 \times\left(\mathrm{T}_{\mathrm{db}} \times \mathrm{RH}\right)\right] \\
-\left[0.073 \times(0.1+\mathrm{RAD})^{-1}\right] ;
\end{gathered}
$$

$\mathrm{TI}_{6}$ : comprehensive climate index (CCI; Mader et al., 2010):

$$
\mathrm{CCI}=\mathrm{RH}_{\text {adj }}+\mathrm{WS}_{\text {adj }}+\mathrm{RAD}_{\text {adj }},[6]
$$

where

$$
\begin{aligned}
& \mathrm{RH}_{\mathrm{adj}}=\mathrm{e}^{\left[(0.00182 \times \mathrm{RH})+\left(1.8 \times 10^{-5} \times \mathrm{T}_{\mathrm{db}} \times \mathrm{RH}\right)\right]} \times\left[\left(0.000054 \times \mathrm{T}_{\mathrm{db}}{ }^{2}\right)\right. \\
& \left.+\left(0.00192 \times \mathrm{T}_{\mathrm{db}}\right)-0.0246\right] \times(\mathrm{RH}-30) ;
\end{aligned}
$$$$
\mathrm{WS}_{\mathrm{adj}}=\left(\frac{-6.56}{e^{\left[\frac{1}{(2.26 \times \mathrm{WS}+0.23)^{0.45}} \times\left[2.9+1.14 \times 10^{-6} \times \mathrm{WS}^{2.5}-\log _{0.3}(2.26 \times \mathrm{WS}+0.33)^{-2}\right]\right.}}\right)
$$$$
-0.0056 \times \mathrm{WS}^{2}+3.33 \text {; }
$$

$$
\begin{aligned}
& \operatorname{RAD}_{\text {adj }}=(0.0076 \times \mathrm{RAD})-\left(0.00002 \times \mathrm{RAD} \times \mathrm{T}_{\mathrm{db}}\right) \\
& +\left(0.00005 \times \mathrm{T}_{\mathrm{db}}{ }^{2} \times \sqrt{R A D}\right)+\left(0.1 \times \mathrm{T}_{\mathrm{db}}\right)-2 .
\end{aligned}
$$

The daily average of each of those 6 indices was calculated for each weather station by averaging hourly values over $24 \mathrm{~h}$. Herds and weather stations were then spatially located based on distances obtained from the zip code. The nearest weather station according to minimum distance to the herd location was designed as the reference for that herd. The mean, maximum, and minimum distances between weather station and herd location were of $7.6,16$, and $1 \mathrm{~km}$, respectively. In this analysis, the mean daily TI of the previous $3 \mathrm{~d}$ before each test day was designed as the TI of reference for that test day.

Indices $\left(\mathrm{TI}_{1}\right.$ to $\left.\mathrm{TI}_{3}\right)$ belong to similar order of magnitude and definition. They will be grouped together in major results and will be referred to as THI indices. The $\mathrm{TI}_{1}$ represents the most worldwide THI used as predictor of heat stress in dairy cattle and other species by most researchers (e.g., team of the University of Georgia, Athens). Both indices $\left(\mathrm{TI}_{2}\right.$ and $\left.\mathrm{TI}_{3}\right)$ are modified THI after adjustment for WS and RAD. The other indices $\left(\mathrm{TI}_{4}\right.$ to $\left.\mathrm{TI}_{6}\right)$ have similar scales as ambient temperature. They will be referred to as apparent temperature indices and grouped together. The $\mathrm{TI}_{4}$ was chosen in this study because it represents the most comprehensive index for lactating dairy cows. It was derived specifically from milk production and heat loss rates evaluation at its development as TI. The last index $\left(\mathrm{TI}_{6}\right)$ has the advantage of covering a wide range of hot and cold conditions compared with all other indices. Mainly, low range temperatures are very suited and remain specific to temperate regions.

\section{Statistical Analysis}

To identify heat stress thresholds for production traits and SCS for each of the 6 studied TI, data were analyzed in a 2-step approach. A similar approach was used to test the effect of maximum outside temperature at day of insemination on reproductive performance of 2 sow lines (Bloemhof et al., 2008). In our study, first a separate random regression test-day model (model 1), assuming no effect of TI, was developed. Variance components were estimated using Remlf90 (Misztal et al., 2002). Test-day milk, fat, protein, and SCS records $\left(\mathrm{y}_{\mathrm{i}}{ }^{*}\right)$ were corrected for fixed effects using solutions obtained from Blup90iod software (Misztal et al., 2002). In matrix notation, model 1 was as follows:

$$
\mathbf{y}=\mathbf{X} \mathbf{b}+\mathbf{Q}(\mathbf{Z a}+\mathbf{Z} \mathbf{p}+\mathbf{W h})+\mathbf{e},
$$

where $\mathbf{y}$ is a vector of test-day production traits or SCS; $\mathbf{b}$ is a vector of the fixed effects: herd $\times$ test-date (HTD), age $\times$ season of calving $\times$ classes of 25 DIM (AGSAI), and classes of 5 DIM (CDIM); $\mathbf{a}$ is a vector of random regression coefficients for animal genetic effect; $\mathbf{p}$ is a vector of random regression coefficients for permanent environmental effect; $\mathbf{h}$ is a vector of 
random regression coefficients for herd-year of calving common environmental effect; $\mathbf{e}$ is a vector of residual effects; $\mathbf{Q}$ is a matrix of Legendre polynomials of order 2; and $\mathbf{X}, \mathbf{Z}$, and $\mathbf{W}$ are incidence matrices relating observations to various effects. Residual variance was assumed constant across DIM.

In the second step, the corrected test-day records $\left(\mathrm{y}_{\mathrm{i}}{ }^{*}\right)$ for production traits and SCS were analyzed separately using a broken-line regression model (model 2) and applying the procedure NLIN (version 9.2; SAS Institute Inc., Cary, NC). Model 2 was defined as follows:

$$
\begin{gathered}
\mathrm{y}_{\mathrm{i}}^{*}=\mathrm{c}+\mathrm{e}_{\mathrm{i}} \text {; when } \mathrm{x}_{\mathrm{i}} \leq \mathrm{THR} \text {, and } \\
\mathrm{y}_{\mathrm{i}}^{*}=\mathrm{a}+\mathrm{b}^{*} \mathrm{x}_{\mathrm{i}}+\mathrm{e}_{\mathrm{i}} ; \text { when } \mathrm{x}_{\mathrm{i}}>\mathrm{THR},
\end{gathered}
$$

where $\mathrm{c}$ is a constant (plateau) when performance is not affected by the thermal comfort condition, $\mathrm{e}_{\mathrm{i}}$ is the random residual term, and $\mathrm{x}_{\mathrm{i}}$ is the value appropriate to each TI scale. The parameter THR is the specific value of each TI for the upper point of the thermoneutral zone. The latter is defined as $(c-a) / b$, where $a=$ intercept and $\mathrm{b}=$ decrease in $\mathrm{y}^{*}$ when each appropriate TI increases by 1 unit.

To study the change in production traits and SCS level with increasing TI values, TI effect was evaluated directly (model 3) by a slight modification of model 1 . Model 3 was as follows:

$$
\begin{gathered}
\mathrm{Y}_{\mathrm{ijklmno}}=\mathrm{HTD}_{\mathrm{i}}+\mathrm{AGSAI}_{\mathrm{j}}+\mathrm{STAGE}_{\mathrm{k}}+\Sigma \phi_{\mathrm{t}} \mathrm{z}_{\mathrm{lr}} \\
+\Sigma \phi_{\mathrm{s}} \mathrm{a}_{\mathrm{mr}}+\Sigma \phi_{\mathrm{s}} \mathrm{p}_{\mathrm{nr}}+\Sigma \phi_{\mathrm{s}} \mathrm{z}_{\mathrm{or}}+\mathrm{e}_{\mathrm{ijk} k \mathrm{mno}},
\end{gathered}
$$

where $z_{l r}$ is the fixed regression coefficients and $\phi_{t}$ are the Legendre polynomial covariables of order 2 evaluated at each corresponding specific TI. The other fixed and random effects were as defined above (model 1).

To quantify the magnitude of production traits decline by each TI above the specific threshold, regression analyses were applied to evaluate changes in test-day records of production traits for different ranges of TI below its respective typing point (model 4). Those ranges represented the mild, moderate, and extreme heat stress level. Model 4 was as follows:

$$
\begin{gathered}
\mathrm{Y}_{\mathrm{ijklmn}}=\mathrm{HTD}_{\mathrm{i}}+\mathrm{AGSAI}_{\mathrm{j}}+\mathrm{STAGE}_{\mathrm{k}}+\beta \times \mathrm{t} \\
+\Sigma \phi_{\mathrm{s}} \mathrm{a}_{\mathrm{lr}}+\Sigma \phi_{\mathrm{s}} \mathrm{p}_{\mathrm{mr}}+\Sigma \phi_{\mathrm{s}} \mathrm{z}_{\mathrm{nr}}+\mathrm{e}_{\mathrm{ijkl} \mathrm{mn}},
\end{gathered}
$$

where

$$
t=\left\{\begin{array}{cc}
0 & \text { if } \mathrm{TI} \leq \mathrm{THR} \\
(\mathrm{TI}-\mathrm{THR}) & \text { if } \mathrm{TI}>\mathrm{THR}
\end{array} .\right.
$$

Following Bohmanova et al. (2007), the yearly loss of milk, fat, and protein due to heat stress was estimated by multiplying the appropriate rate of decline (b) of each TI by the yearly cumulated stressed degrees below the specific threshold of each TI. Yearly loss was computed for each separate weather station.

\section{RESULTS AND DISCUSSION}

\section{Climate Conditions in Luxembourg}

Luxembourg is characterized by a continental temperate climate known by mild winters and pleasant temperatures in summer. The average daily $\mathrm{T}_{\mathrm{db}}, \mathrm{RH}$, $\mathrm{WS}$, and RAD from the 14 weather stations used in our study during the 12 years were $9.98^{\circ} \mathrm{C}, 81 \%, 1.95$ $\mathrm{m} / \mathrm{s}$, and $100 \mathrm{~W} / \mathrm{m}^{2}$, respectively. The northern part is slightly warmer $\left(\mathrm{T}_{\mathrm{db}}=10.62^{\circ} \mathrm{C}\right)$ and less humid $(\mathrm{RH}$ $=79 \%)$ than the southern part $\left(\mathrm{T}_{\mathrm{db}}=9.36^{\circ} \mathrm{C}\right.$ and $\mathrm{RH}$ $=83 \%)$. Nevertheless, given its limited geographical extent, Luxembourg hardly presents large climatic contrasts. Mean monthly $\mathrm{T}_{\mathrm{db}}$ and RAD were lowest in January and peaked in July (Figure 1). Monthly averages RAD formed a plateau of around $160 \mathrm{~W} / \mathrm{m}^{2}$ from May to August. In contrast, $\mathrm{RH}$ had a reverse trend to $\mathrm{T}_{\mathrm{db}}$ and RAD. The WS was constant during the year, with an average of $2 \mathrm{~m} / \mathrm{s}$. The grazing period in Luxembourg occurs between April and November where cows have free access to the outdoors for an average of $8 \mathrm{~h}$ per day (Dairyman, 2012). During this period, cows are exposed to the highest levels of $\mathrm{T}_{\mathrm{db}}$ and RAD and, thus, could be affected by heat stress during July and August, when the latter parameters attempt their peaks.

Both THI and apparent temperature indices had similar yearly trends, labeled with lowest values from November to January and highest values from June to August (Figure 2). The largest differences between all TI were observed during those 2 contrasted seasons. Similar patterns were reported by Bohmanova et al. (2007) when evaluating $\mathrm{TI}_{1}$ and 6 other variants of THI weighted differently only on $\mathrm{T}_{\mathrm{db}}$ and $\mathrm{RH}$ under the climatic conditions of Georgia and Arizona. Their THI values were higher compared with THI indices defined in the current study. In addition, Bohmanova et al. (2007) observed that the largest differences between THI indices were only associated with the summer season under the humid and the semiarid environment in the United States.

Correlations between the 6 TI evaluated in this study were high. They ranged from 0.73 (between $\mathrm{TI}_{3}$ and $\mathrm{TI}_{4}$ ) to more than 0.95 among the other 5 indices. Moreover, the different TI were highly correlated to $\mathrm{T}_{\mathrm{db}}$. Correlation coefficients ranged from $0.77\left(\mathrm{TI}_{3}\right)$ to $0.99\left(\mathrm{TI}_{1}\right)$. Howev- 


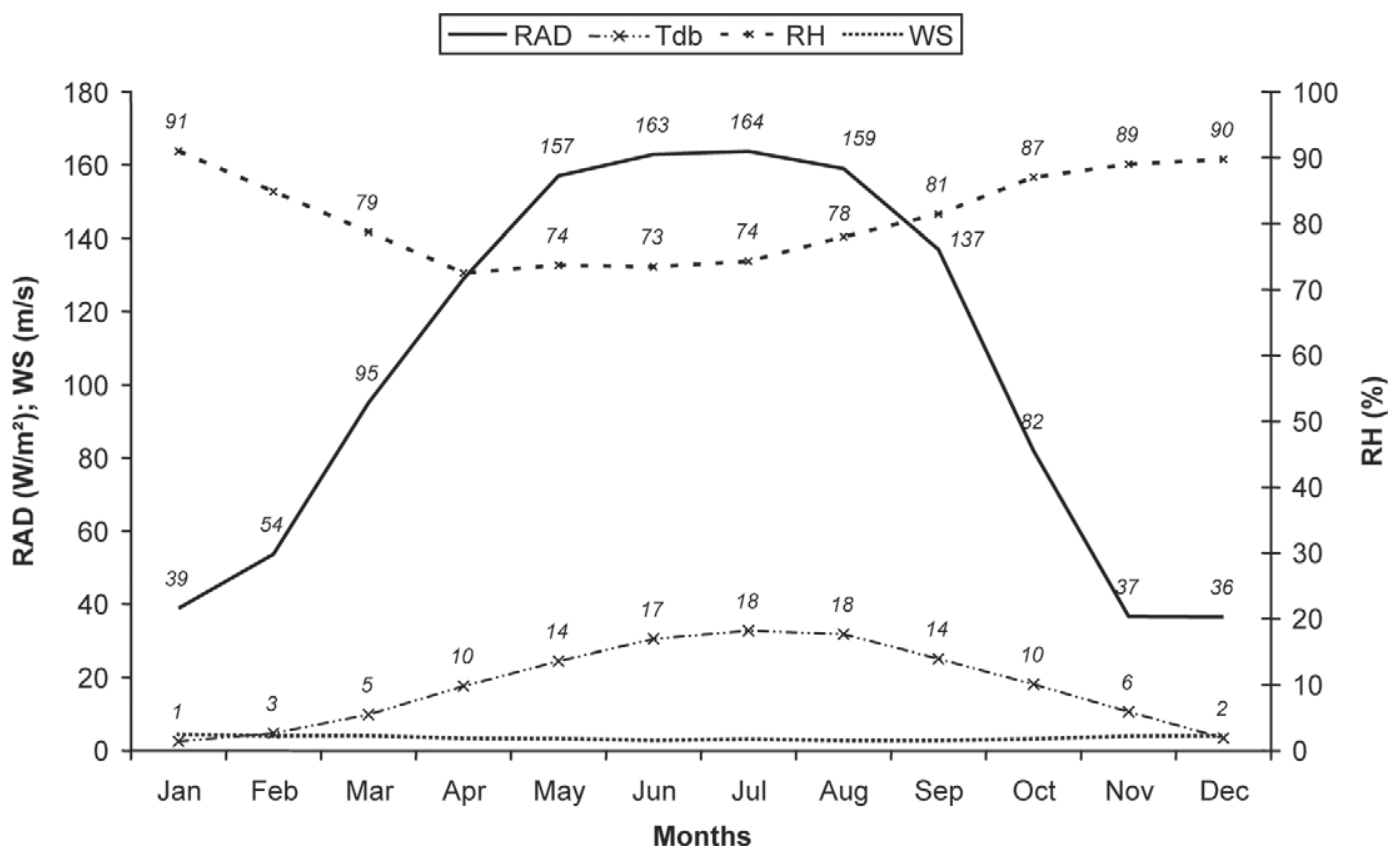

Figure 1. Average monthly temperature $\left(\mathrm{T}_{\mathrm{db}},{ }^{\circ} \mathrm{C}\right)$, relative humidity $(\mathrm{RH}, \%)$, wind speed $(\mathrm{WS} ; \mathrm{m} / \mathrm{s})$, and solar radiation $\left(\mathrm{RAD} ; \mathrm{W} / \mathrm{m}^{2}\right)$ in Luxembourg.

er, they were less correlated to the other meteorological parameters (RH, WS, and RAD). Correlations were low and ranged from $-0.27\left(\mathrm{TI}_{3}\right)$ to $-0.52\left(\mathrm{TI}_{4}\right)$ with $\mathrm{RH}$, $-0.09\left(\mathrm{TI}_{5}\right)$ to $-0.33\left(\mathrm{TI}_{2}\right)$ with $\mathrm{WS}$, and $0.37\left(\mathrm{TI}_{1}\right)$ to $0.67\left(\mathrm{TI}_{3}\right)$ with RAD. Dikmen and Hansen (2009) evaluated under a subtropical climate conditions 7 THI indices similarly defined to those used by Bohmanova et al. (2007). They reported high correlations $(\mathrm{r}=0.93$

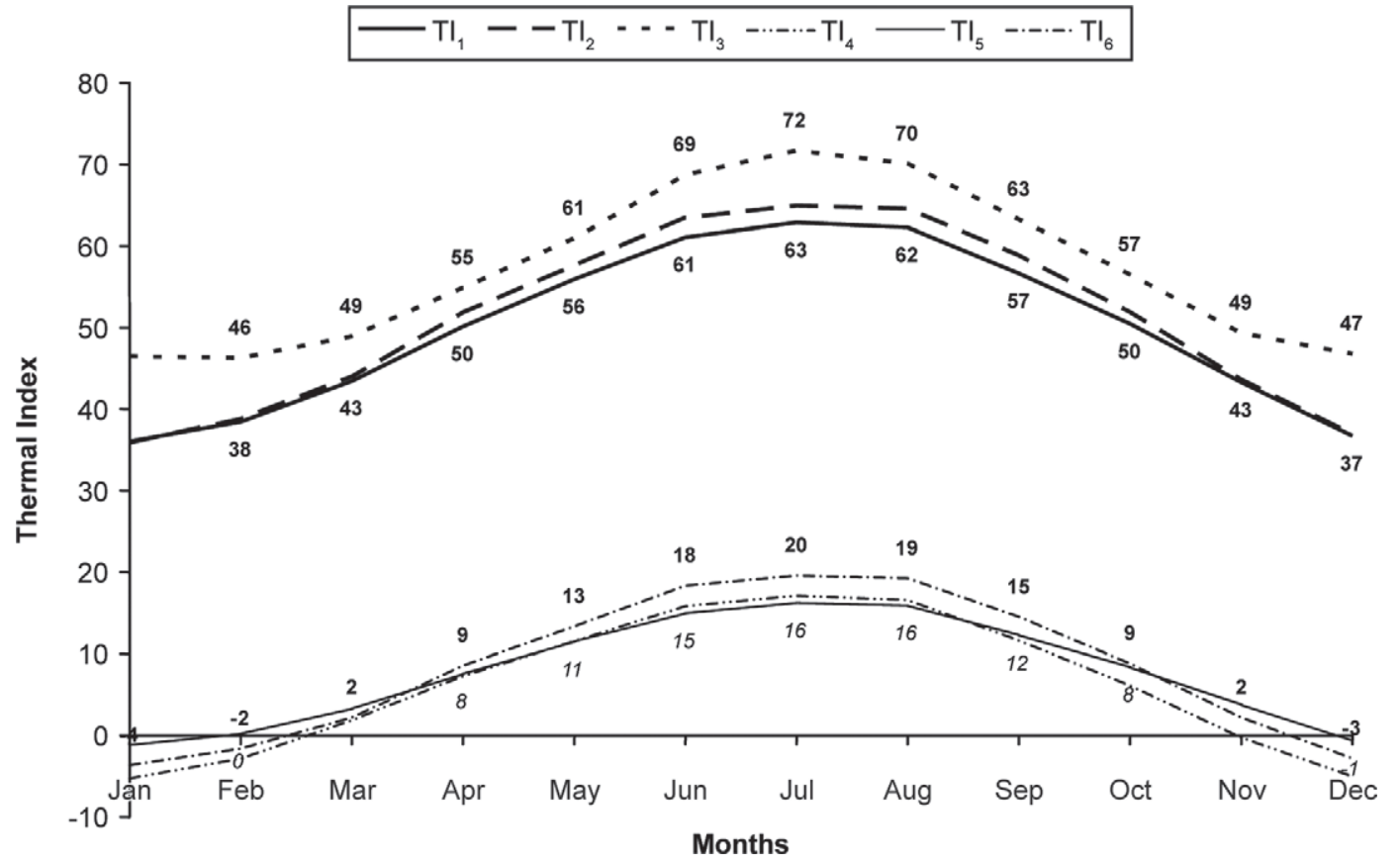

Figure 2. Average monthly values of temperature-humidity $\left(\mathrm{TI}_{1}, \mathrm{TI}_{2}\right.$, and $\left.\mathrm{TI}_{3}\right)$ and apparent temperature $\left(\mathrm{TI}_{4}, \mathrm{TI}_{5}\right.$, and $\left.\mathrm{TI}_{6}\right)$ indices in Luxembourg. $\mathrm{TI}_{1}=$ temperature-humidity index (THI; NRC, 1971); $\mathrm{TI}_{2}=$ adjusted THI (Mader et al., 2006); $\mathrm{TI}_{3}=$ heat load index $(\mathrm{Gaughan}$ et al., 2008); $\mathrm{TI}_{4}=$ equivalent temperature index (Baeta et al., 1987); $\mathrm{TI}_{5}=$ environmental stress index $\left(\mathrm{Moran}\right.$ et al., 2001); $\mathrm{TI}_{6}=$ comprehensive climate index (Mader et al., 2010). 
to 1) between all indices. The authors showed also that the highest correlations were observed between the 7 THI indices and $\mathrm{T}_{\mathrm{db}}(\mathrm{r}=0.84$ to 0.98$)$.

\section{Identification of Heat Stress Thresholds}

Least squares means from ANOVA (model 3) using regressions on THI and apparent temperature indices are presented in Figures 3 and 4, respectively. A plateau-linear relationship was identified for almost all production traits and SCS. Estimates of thresholds were different among the studied TI (Table 1). They ranged from $62\left(\mathrm{TI}_{1}\right)$ to $80\left(\mathrm{TI}_{3}\right)$ for THI indices and production traits. Corresponding values for apparent temperature indices ranged from $16\left(\mathrm{TI}_{5}\right)$ to $20\left(\mathrm{TI}_{6}\right)$. Direct comparison of thresholds among the evaluated indices is difficult not only because of the scaling effect but also due to differences in weights on $\mathrm{T}_{\mathrm{db}}, \mathrm{RH}$, WS, and RAD for each of them. Nevertheless, it is interesting to notice that all of the 6 different threshold estimates correspond to average $\mathrm{T}_{\mathrm{db}}\left(17.8 \pm 1.2^{\circ} \mathrm{C}\right)$ and $\mathrm{RH}(75 \pm 9 \%)$ independent of WS and RAD. Our estimates of the upper critical temperature are lower than values of upper critical temperatures of 23 and $30^{\circ} \mathrm{C}$ found in the United States humid and semiarid environments, respectively (Bohmanova et al., 2007), $27^{\circ} \mathrm{C}$ reported under Arizona climate conditions (Igono et al., 1992), $28.4^{\circ} \mathrm{C}$ in a subtropical environment (Dikmen and Hansen, 2009), and $25^{\circ} \mathrm{C}$ estimated under the Mediterranean climate of Israel (Berman et al., 1985). However, our estimates are consistent with the value of $16^{\circ} \mathrm{C}$ reported by Youssef (1985) as the upper critical temperature point.

Different thresholds of heat stress for production traits in dairy cattle were reported using different TI definitions and dairy populations (Dikmen and Hansen, 2009; Boonkum et al., 2011; Brügemann et al., 2011). However, TI1 remains the de facto indicator of heat stress for livestock exposed to hot weather. A threshold value of 72 TI1 was identified as the upper critical point for milk decline of Holsteins in a US humid environment (Bohmanova et al., 2007). The threshold of the same index was 74 in a semiarid US environment (Bohmanova et al., 2007), 78 in a subtropical US environment (Dikmen and Hansen, 2009), 80 under climatic conditions of Thailand (Boonkum et al., 2011), 69 under the Mediterranean climate conditions of Tunisia (Bouraoui et al., 2002), and 60 for protein yield of German Holsteins (Brügemann et al., 2011). Most studies conducted in Europe were restricted mainly to the eastern part. They focused exclusively on the TI1 effect on milk production and mostly arbitrarily chose 72 as the threshold (Broucek et al., 2007; Reiczigel et al., 2009; Gantner et al., 2011).
Thresholds of heat stress for TI that considered heat radiation load and wind effect in addition to $T_{d b}$ and $\mathrm{RH}$ were limited to the experimental studies used for the development of those indices (Baeta et al., 1987; Mader et al., 2010) and only 1 small experimental data set under tropical conditions (Silva et al., 2007). Threshold estimates for milk yield were 89 for TI4 (Silva et al., 2007) and 26 and 30 arbitrarily defined for TI4 by Baeta et al. (1987) and Silva et al. (2007), respectively. Threshold estimates for TI6 were also arbitrarily defined by Mader et al. (2010) for both cold conditions $(0$ to -10$)$ and hot conditions (25 to 30$)$.

The overall thresholds for heat stress of the 6 TI as identified for production traits and SCS in our study (Table 1) were different and lower than almost all threshold estimates in tropical, subtropical, and Mediterranean climatic conditions. But the threshold for TI1 is still in the same range as estimates for German Holsteins (Brügemann et al., 2011). These results demonstrate that responses to heat stress varied between regions and environments and that Holsteins differed in their adaptation to thermal environments. The lowest threshold values observed for all indices in our study could be potentially assigned to a reduced adaptability of Luxembourg Holsteins to heat stress under continental temperate conditions. In addition, the intensive selection mainly for high yields, considering heat stress as "strange" phenomena under their conditions, could explain the highest sensitivity of Holsteins under temperate regions. Maróti-Agóts et al. (2011) reported that the extensive keeping of the indigenous Hungarian Grey breed under the warm and hot Hungarian conditions for several centuries may have proved to be a selection pressure for heat tolerance when compared with Norwegian Red cattle. They pointed out that the effective response to heat stress of Norwegian cattle seems to be less important than that expressed by the Hungarian Grey breed. Boonkum et al. (2011) justified the high threshold of 80 TI1 for the Thai crossbred population by the combinations of heat tolerance genes from Bos indicus and the low level of production under more restricted feeding opportunities in Thailand. Dikmen and Hansen (2009) advocate that the high difference in thresholds for $\mathrm{TI}_{1}$ of 68 and 78 observed between Georgia and Florida could be explained by better adaptation of Holsteins under climate conditions of Georgia. They also stressed the beneficial effect of housing and cooling features to reduce the heat stress effect. In our study, and similar to most temperate regions, there is a lack of use of cooling practices compared with farmers in subtropical regions. In subtropical regions, the use of cooling devices to mitigate the effects of high temperatures could explain the higher thresholds observed compared with our estimates. Moreover, the outdoor 

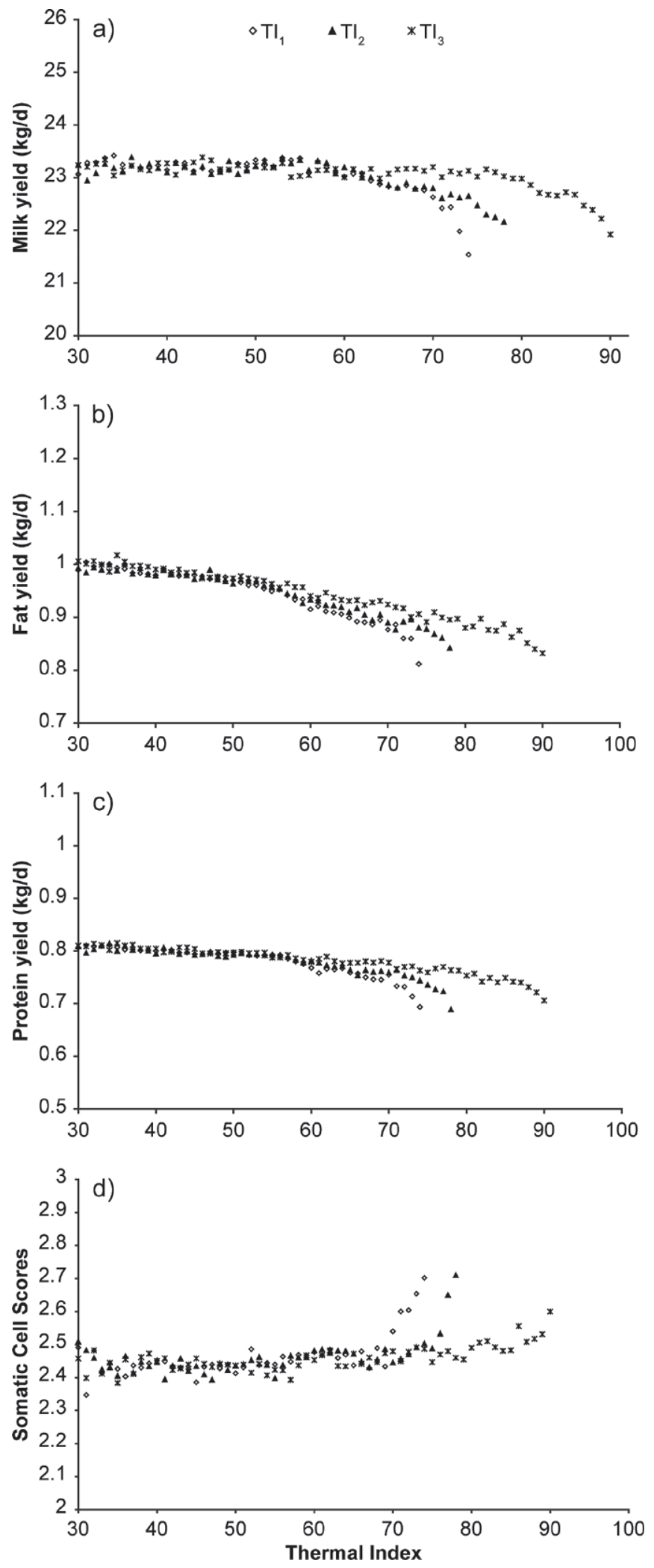

Figure 3. Least squares means for daily (a) milk, (b) fat, (c) protein yields, and (d) SCS when using temperature-humidity indices. $\mathrm{TI}_{1}$ = temperature-humidity index (THI; NRC, 1971); $\mathrm{TI}_{2}=$ adjusted $\mathrm{THI}$ (Mader et al., 2006); $\mathrm{TI}_{3}=$ heat load index (Gaughan et al., 2008). presence in the grazing period under unstructured shades during summer months in Luxembourg should be considered as additional potential environmental sources behind these lowest thresholds among those reported for Holstein populations. Access to indoor or outdoor structures providing shade during this period would lessen the heat load effect. Despite the ability of shade structures to alleviate the radiant heat load, the typical shade structure used in Israel was found to add $3^{\circ} \mathrm{C}$ to the ambient temperature surrounding animals (Berman, 2005). Under shade structures, cooling systems based on fans also produce varying convection levels.

With regard to milk composition, the tipping point at which milk fat was affected by the different studied TI in this work were not well established when compared with those found for milk and protein yields (Figures 3 and 4). Fat yields tend to decrease steadily with increasing THI and similarly with apparent temperature indices. Almost for all TI, the values of thresholds were obtained, whereas the convergence criterion was not met (Table 1). Milk protein remains almost constant before the specific thresholds to each TI, after which it decreased by an average of the b value associated with each TI (Figures 3 and 4; Table 1). McDowell (1976) stated that fat was more altered than proteins under high temperature. McDowell (1976) reported that fat, SNF, and milk protein percentage decreased by 40 , 19 , and $17 \%$, respectively, when $\mathrm{T}_{\mathrm{db}}$ increased from 18 to $30.8^{\circ} \mathrm{C}$. The depressed milk protein levels due to heat stress after the upper critical point was generally pointed out by other studies (Bouraoui et al., 2002; Gantner et al., 2011). The steady decrease in fat in our study was observed in the ranges of TI corresponding to the medium-high $\mathrm{T}_{\mathrm{db}}$ of spring to summer seasons. During the later periods, cows generally graze where heat load and high $\mathrm{T}_{\mathrm{db}}$ effects under unstructured shades are effective. The decrease in forage intake and the inadequate fiber levels in the rations will contribute to a decrease in fat yield. The decrease in protein yields could be caused by a decrease in DMI and energy intake during the heat stress period.

The daily SCS patterns for all TI were different from those observed for milk, fat, and protein yields (Figures 3 and 4). In contrast to the tendency of the latter, the tendency was for increased SCS values at both the lowest and highest TI ranges. Medium to marginal increases in SCS levels were observed for THI, whereas a more pronounced reaction to cold stress was clearer for apparent temperature indices (mainly $\mathrm{TI}_{4}$ ). Thresholds identified for both THI and apparent temperature indices were higher than those observed for production traits. Shathele (2009) reported that occurrence of mastitis is more pronounced during low ambient tem- 
perature and cold stress. Igono et al. (1988) reported that modest increases in milk SCC were observed in heat-stressed cows, using THI $\left(\mathrm{TI}_{1}\right)$ as an indicator. The higher SCC in milk observed in the current study after the upper critical point for cold and heat stress could be explained by the depressive immune function due to the oxidative stress effect. Godden et al. (2003) stated that heat and humidity did increase the pathogen load in housed or in field environment, resulting in a great incidence of mastitis.

\section{Milk, Fat, and Protein Yield Losses Due to Heat Stress}

The production trait decline per unit of mild, moderate, and extreme ranges of TI varied between indices (Table 2). For milk, they ranged from $0.164 \mathrm{~kg} / \mathrm{TI}_{1}$ to $0.109 \mathrm{~kg} / \mathrm{TI}_{5}$ and from $0.955 \mathrm{~kg} / \mathrm{TI}_{1}$ to $0.298 \mathrm{~kg} / \mathrm{TI}_{3}$ in mild and extreme situations of heat stress, respectively. The highest milk fat rates of decline were $0.051 \mathrm{~kg} / \mathrm{TI}_{5}$ and $0.095 \mathrm{~kg} / \mathrm{TI}_{5}$ in mild situations and in extreme heat stress situations, respectively. Corresponding values for protein yield were $0.013 \mathrm{~kg} / \mathrm{TI}_{1}$ and $0.062 \mathrm{~kg} / \mathrm{TI}_{5}$, respectively. Bohmanova et al. (2007) reported that milk loss per unit of each of the 7 THI indices weighted differently only on $\mathrm{T}_{\mathrm{db}}$ and $\mathrm{RH}$ varied among indices and regions. The rate of milk yield decline reported in their study at the threshold point (mild stage) ranged from 0.40 to $0.27 \mathrm{~kg}$ and from 0.59 to $0.23 \mathrm{~kg}$ per unit of THI in Athens (Georgia) and Phoenix (Arizona), respectively. Ravagnolo and Misztal (2000) determined that milk, fat, and protein yields declined, respectively, by $0.2,0.012$, and $0.009 \mathrm{~kg} /$ unit increase in $\mathrm{TI}_{1}$ when $\mathrm{TI}_{1}$ exceeded the THR of 72 . Bouraoui et al. (2002) found higher losses in daily milk, fat, and protein yields $(0.41,0.681$, and $0.562 \mathrm{~kg}$, respectively) per unit increase in $\mathrm{TI}_{1}$ when the threshold of 68 was exceeded. Comparison among indices within and between regions based on decline rate is difficult due to differences in TI definitions, threshold levels, and number of heat-stress days.

The yearly milk, fat, and protein yield losses identified by THI indices were higher than those identified by apparent temperature indices (Figure 5). For THI indices, the largest losses of milk, fat, and protein of 54, 5.7 , and $4.2 \mathrm{~kg}$, respectively, were identified by $\mathrm{TI}_{2}$, the de facto indicator (THI), which is adjusted for WS and RAD. The lowest yearly milk, fat, and protein losses were identified by the apparent temperature index $\mathrm{TI}_{5}$, with $24,3.2$, and $2.4 \mathrm{~kg}$, respectively. The year 2003 had the highest TI values among the $12 \mathrm{yr}$ evaluated in this study, with a minimum of 20 additional heatstress days to the average. During 2003, $\mathrm{TI}_{2}$ had also the greatest effect on milk, fat, and protein yield. The
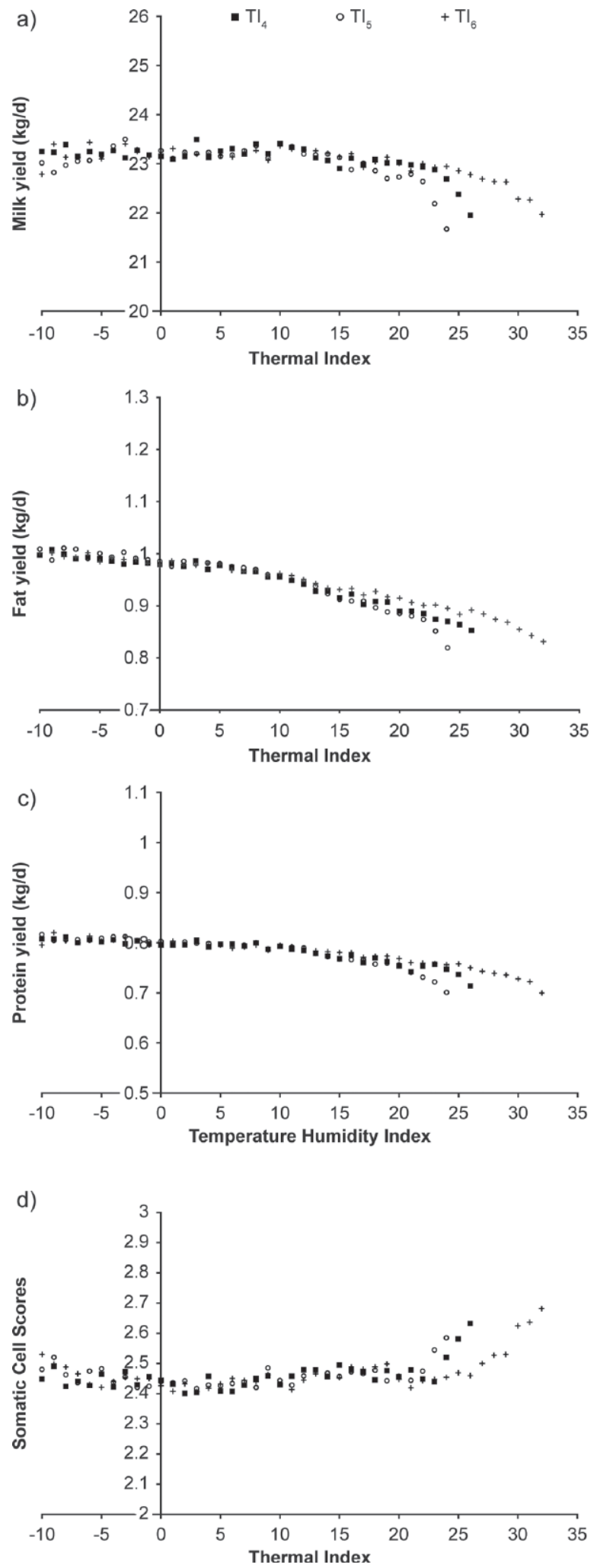

Figure 4. Least squares means for daily (a) milk, (b) fat, (c) protein yields, and (d) SCS when using apparent temperature indices. $\mathrm{TI}_{4}$ $=$ equivalent temperature index (Baeta et al., 1987); $\mathrm{TI}_{5}=$ environmental stress index (Moran et al., 2001); $\mathrm{TI}_{6}=$ comprehensive climate index (Mader et al., 2010). 
Table 1. Nonlinear analysis of milk, fat, protein, and SCS test-day records using the broken-line model (model 2)

\begin{tabular}{|c|c|c|c|c|c|}
\hline Trait & $\begin{array}{l}\text { Thermal } \\
\text { index }(\mathrm{TI})^{1}\end{array}$ & $a^{2}$ & $b^{3}$ & $c^{4}$ & $\mathrm{THR}^{5}$ \\
\hline \multirow[t]{6}{*}{ Milk (kg) } & $\mathrm{TI}_{1}$ & 25.1 & -0.164 & 23.3 & 62 \\
\hline & $\mathrm{TI}_{2}$ & 25.3 & -0.152 & 22.8 & 64 \\
\hline & $\mathrm{TI}_{3}$ & 24.2 & -0.123 & 23.8 & 80 \\
\hline & $\mathrm{TI}_{4}$ & 23.5 & -0.146 & 22.9 & 18 \\
\hline & $\mathrm{TI}_{5}$ & 23.7 & -0.109 & 22.2 & 16 \\
\hline & $\mathrm{TI}_{6}$ & 23.6 & -0.154 & 23.2 & 20 \\
\hline \multirow[t]{6}{*}{ Fat (kg) } & $\mathrm{TI}_{1}$ & 1.05 & -0.020 & 0.98 & 62 \\
\hline & $\mathrm{TI}_{2}$ & 1.05 & -0.014 & 1.01 & $64^{*}$ \\
\hline & $\mathrm{TI}_{3}$ & 1.02 & -0.013 & 1.02 & $80^{*}$ \\
\hline & $\mathrm{TI}_{4}$ & 0.99 & -0.022 & 0.99 & $18^{*}$ \\
\hline & $\mathrm{TI}_{5}$ & 1.01 & -0.023 & 0.99 & 16 \\
\hline & $\mathrm{TI}_{6}$ & 1.00 & -0.021 & 0.99 & $20^{*}$ \\
\hline \multirow[t]{6}{*}{ Protein $(\mathrm{kg})$} & $\mathrm{TI}_{1}$ & 0.86 & -0.013 & 0.80 & 62 \\
\hline & $\mathrm{TI}_{2}$ & 0.87 & -0.012 & 0.82 & 64 \\
\hline & $\mathrm{TI}_{3}$ & 0.84 & -0.010 & 0.83 & 80 \\
\hline & $\mathrm{TI}_{4}$ & 0.83 & -0.012 & 0.82 & 18 \\
\hline & $\mathrm{TI}_{5}$ & 0.83 & -0.011 & 0.81 & 16 \\
\hline & $\mathrm{TI}_{6}$ & 0.83 & -0.013 & 0.81 & 20 \\
\hline \multirow[t]{6}{*}{ SCS } & $\mathrm{TI}_{1}$ & 2.22 & 0.002 & 2.66 & 66 \\
\hline & $\mathrm{TI}_{2}$ & 2.24 & 0.002 & 2.42 & 71 \\
\hline & $\mathrm{TI}_{3}$ & 2.26 & 0.005 & 2.37 & 82 \\
\hline & $\mathrm{TI}_{4}$ & 2.29 & 0.004 & 2.39 & 21 \\
\hline & $\mathrm{TI}_{5}$ & 2.37 & 0.003 & 2.52 & 20 \\
\hline & $\mathrm{TI}_{6}$ & 2.38 & 0.004 & 2.44 & 23 \\
\hline
\end{tabular}

${ }^{1} \mathrm{TI}_{1}=$ temperature-humidity index (THI; NRC, 1971); $\mathrm{TI}_{2}=$ adjusted THI (Mader et al., 2006); $\mathrm{TI}_{3}=$ heat load index (Gaughan et al., 2008); $\mathrm{TI}_{4}=$ equivalent temperature index (Baeta et al., 1987); $\mathrm{TI}_{5}=$ environmental stress index (Moran et al., 2001); $\mathrm{TI}_{6}=$ comprehensive climate index (Mader et al., 2010).

${ }^{2}$ Intercept.

${ }^{3}$ The slope of the decrease in corrected trait $\left(\mathrm{y}^{*}\right)$ when the thermal index decreases by 1 unit.

${ }^{4}$ The plateau when the trait is not affected by the thermal comfort.

${ }^{5}$ The threshold of each TI for the upper point of the thermoneutral zone.

*The convergence criterion was not met.

Table 2. Rate of decline for milk, fat, and protein yields at mild, moderate, and extreme heat stress levels

\begin{tabular}{llrrrr}
\hline Heat stress level & $\begin{array}{l}\text { Thermal } \\
\text { index }(\mathrm{TI})^{1}\end{array}$ & Range & Milk $(\mathrm{kg})$ & Fat $(\mathrm{kg})$ & $\begin{array}{c}\text { Protein } \\
(\mathrm{kg})\end{array}$ \\
\hline Upper critical point $(\mathrm{THR})^{2}$ & $\mathrm{TI}_{1}$ & 62 & 0.164 & 0.020 & 0.013 \\
& $\mathrm{TI}_{2}$ & 64 & 0.152 & 0.014 & 0.012 \\
& $\mathrm{TI}_{3}$ & 80 & 0.123 & 0.013 & 0.010 \\
& $\mathrm{TI}_{4}$ & 18 & 0.146 & 0.022 & 0.012 \\
& $\mathrm{TI}_{5}$ & 16 & 0.109 & 0.023 & 0.011 \\
& $\mathrm{TI}_{6}$ & 20 & 0.154 & 0.021 & 0.013 \\
$\mathrm{TI}_{1}$ & $62-70$ & 0.356 & 0.032 & 0.022 \\
& $\mathrm{TI}_{2}$ & $64-72$ & 0.252 & 0.019 & 0.013 \\
$\mathrm{TI}_{3}$ & $80-88$ & 0.188 & 0.024 & 0.016 \\
& $\mathrm{TI}_{4}$ & $18-23$ & 0.339 & 0.042 & 0.022 \\
& $\mathrm{TI}_{5}$ & $16-21$ & 0.298 & 0.051 & 0.033 \\
& $\mathrm{TI}_{6}$ & $20-27$ & 0.214 & 0.026 & 0.017 \\
$\mathrm{TI}_{1}$ & $70-74$ & 0.955 & 0.077 & 0.052 \\
& $\mathrm{TI}_{2}$ & $72-78$ & 0.535 & 0.048 & 0.031 \\
& $\mathrm{TI}_{3}$ & $88-92$ & 0.298 & 0.041 & 0.023 \\
$\mathrm{TI}_{4}$ & $23-26$ & 0.758 & 0.062 & 0.044 \\
$\mathrm{TI}_{5}$ & $21-24$ & 0.747 & 0.095 & 0.062 \\
$\mathrm{TI}_{6}$ & $27-30$ & 0.315 & 0.044 & 0.046 \\
\hline
\end{tabular}

${ }^{1} \mathrm{TI}_{1}=$ temperature-humidity index (THI; NRC, 1971); $\mathrm{TI}_{2}=$ adjusted THI (Mader et al., 2006); $\mathrm{TI}_{3}=$ heat load index (Gaughan et al., 2008); $\mathrm{TI}_{4}=$ equivalent temperature index (Baeta et al., 1987); $\mathrm{TI}_{5}=$ environmental stress index (Moran et al., 2001); $\mathrm{TI}_{6}=$ comprehensive climate index (Mader et al., 2010).

${ }^{2} \mathrm{THR}=$ threshold of each $\mathrm{TI}$ for the upper point of the thermoneutral zone. 
a) Average $2003 \multimap$ Days - $\longleftarrow-2003$

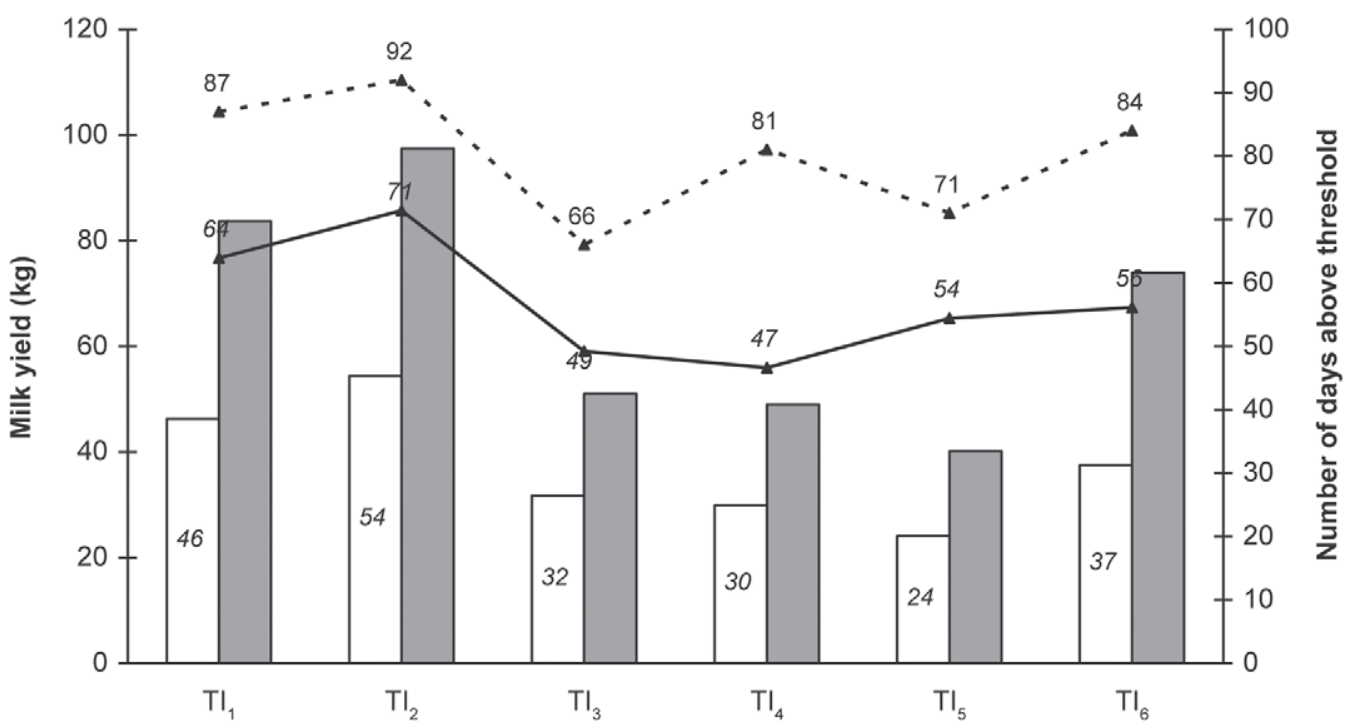

b)

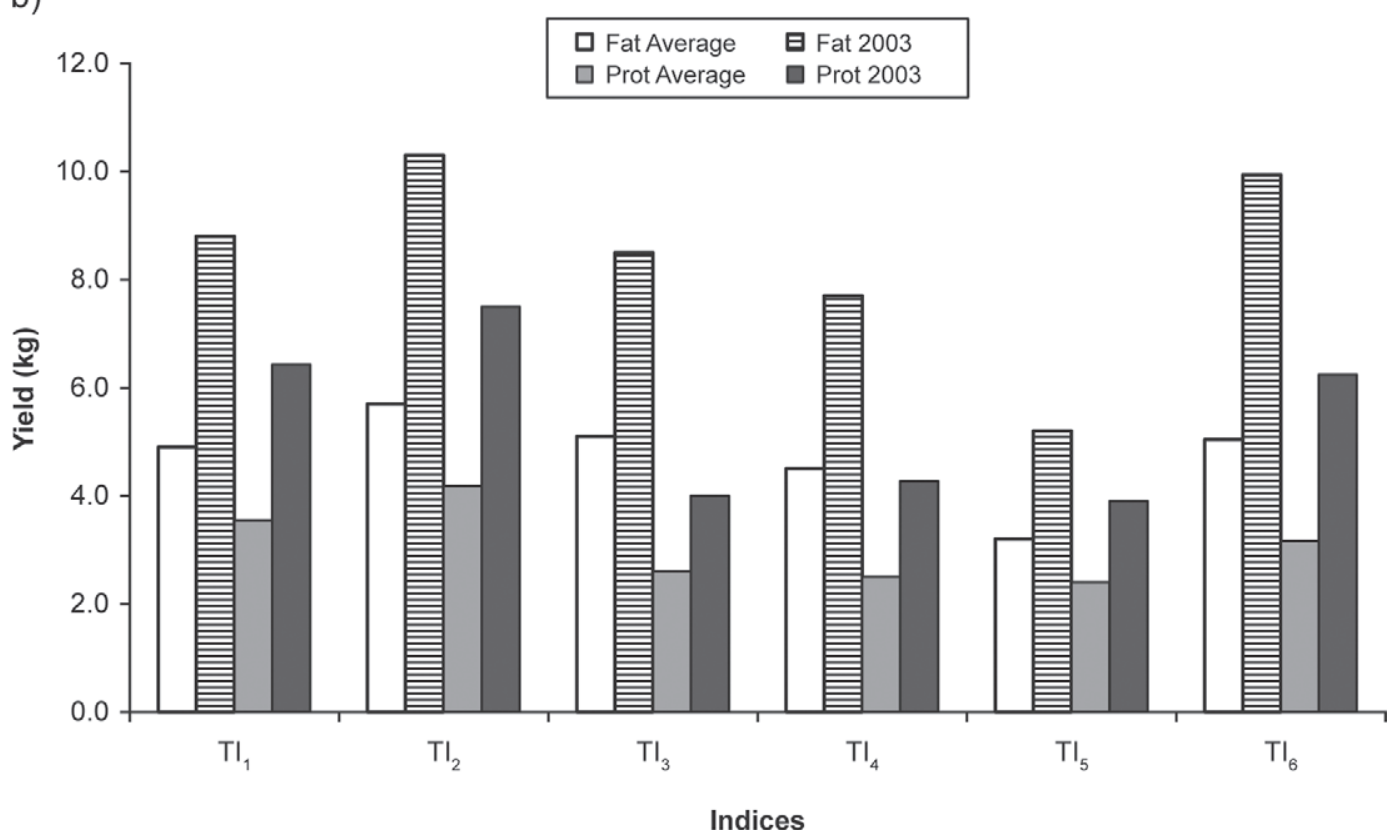

Figure 5. Average yearly loss from 2000 to 2011 and during the year 2003 of (a) milk and (b) fat and protein (Prot) yields and the average number of days of heat stress from 2000 to 2011 and during 2003 for each of the different thermal indices. $\mathrm{TI}_{1}=$ temperature-humidity index (THI; NRC, 1971); $\mathrm{TI}_{2}=$ adjusted THI (Mader et al., 2006); $\mathrm{TI}_{3}=$ heat load index (Gaughan et al., 2008); $\mathrm{TI}_{4}=$ equivalent temperature index (Baeta et al., 1987); $\mathrm{TI}_{5}=$ environmental stress index (Moran et al., 2001); $\mathrm{TI}_{6}=$ comprehensive climate index (Mader et al., 2010).

latter declined by 97, 10.3, and $7.5 \mathrm{~kg}$, respectively. Yearly milk yield losses during this exceptional year remain in the same range of milk losses confirmed by Bohmanova et al. (2007) in the US environment. Those authors reported that milk yield losses ranged from 101 to $127 \mathrm{~kg}$ in Athens (Georgia) and from 124 to $168 \mathrm{~kg}$ in Phoenix (Arizona).
In the current study, losses of production traits yields due to heat stress were confirmed. The decline was lower than values reported in regions with long, hot summers. However, the declines observed in 2003, the particular and extreme heat-stress year in European countries, approached the values observed in hot regions. The most appropriate heat stress indicator was mainly identified 
in this study as the TI with the largest losses on production traits during the year. The residual variances and Akaike information criterion values obtained using model 3 could also be used to compare the different TI. For milk yield, estimates of residual variances and Akaike information criterion values varied from 4.229 $\mathrm{kg}^{2}\left(\mathrm{TI}_{1}\right)$ to $4.321 \mathrm{~kg}^{2}\left(\mathrm{TI}_{6}\right)$ and from 419,863 $\left(\mathrm{TI}_{6}\right)$ to $444,286\left(\mathrm{TI}_{3}\right)$, respectively. The 2 indices adjusted simultaneously for WS and RAD $\left(\mathrm{TI}_{2}\right.$ and $\left.\mathrm{TI}_{6}\right)$ showed significant high production losses in average and in the year with the most heat stress. They were considered as the best indicators among the 6 indices to evaluate heat stress effects for production traits and SCS under a temperate climate. The apparent temperature index $\left(\mathrm{TI}_{6}\right)$ has the advantage of covering a wider range of cold and hot conditions. However, the index complexity definition should be taken into account when developing phenotypic or genetic tools for heat stress mitigation or adaptation.

\section{CONCLUSIONS}

According to our results, all THI and apparent temperature indices had identified heat stress thresholds for the production traits and SCS in Luxembourg Holsteins. The thresholds were lower compared with estimates under tropical, subtropical, and Mediterranean climate conditions. The lowest threshold values could be potentially attributed to a reduced adaptability of Holsteins to heat stress under temperate conditions. However, the conventional THI $\left(\mathrm{TI}_{1}\right)$ could be used as heat stress indicator in temperate regions. Its adjustment for WS and RAD (likewise done for $\mathrm{TI}_{2}$ ) is better to assess animal discomfort under those environments. Because of its ease of use, $\mathrm{TI}_{2}$ may be the best choice for preliminary heat stress forecast and herd management at the phenotypic level in temperate regions. Nevertheless, genetic tolerance to heat stress should be investigated.

\section{ACKNOWLEDGMENTS}

This study was supported and financed by the National Fund for Scientific Research (F.R.S.-FNRS, Brussels, Belgium) through a postdoctoral fellowship. H. Hammami, postdoctoral researcher and Nicolas Gengler, honorary senior research associate, acknowledge the FNRS for these positions and for the additional grants 2.4507.02F(2) and F4552.05 (2.4.623.08.F). The authors thank CONVIS Herdbuch, Service Elevage et Génétique and Administration des services technique de l'agriculture in Luxembourg for providing access to cow performances and climate data. Catherine Bastin (Gembloux Agro-Bio Tech, University of Liège, Gem- bloux, Belgium) is acknowledged for her valuable comments and suggestions.

\section{REFERENCES}

Aguilar, I., I. Misztal, and S. Tsuruta. 2009. Genetic components of heat stress for dairy cattle with multiple lactations. J. Dairy Sci. 92:5702-5711.

Aguilar, I., I. Misztal, and S. Tsuruta. 2010. Genetic trends of milk yield under heat stress for US Holsteins. J. Dairy Sci. 93:17541758.

Baeta, F. C., N. F. Meador, M. D. Shanklin, and H. D. Johnson. 1987. Equivalent temperature index at temperatures above the thermoneutral for lactating dairy cows. ASAE Paper No. 874015. American Society of Agricultural Engineers (ASAE), St. Joseph, MI.

Berman, A. 2005. Estimates of heat stress relief needs for Holstein dairy cows. J. Anim. Sci. 83:1377-1384.

Berman, A., Y. Folman, M. Kaim, M. Mamen, Z. Herz, D. Wolfenson, A. Arieli, and Y. Graber. 1985. Upper critical temperatures and forced ventilation effects for high-yielding dairy cows in a subtropical climate. J. Dairy Sci. 68:1488-1495.

Berry, I. L., M. D. Shanklin, and H. D. Johnson. 1964. Dairy shelter design based on milk production decline as affected by temperature and humidity. Trans. ASAE 7:329-331.

Bianca, W. 1962. Relative importance of dry- and wet-bulb temperatures in causing heat stress in cattle. Nature 195:251-252.

Bloemhof, S., E. H. van der Waaij, J. W. M. Merks, and E. F. Knol. 2008. Sow line differences in heat stress tolerance expressed in reproductive performance traits. J. Anim. Sci. 86:3330-3337.

Bohmanova, J., I. Misztal, and J. B. Cole. 2007. Temperature-humidity indices as indicators of milk production losses due to heat stress. J. Dairy Sci. 90:1947-1956.

Bohmanova, J., I. Misztal, S. Tsuruta, H. D. Norman, and T. J. Lawlor. 2005. National genetic evaluation of milk yield for heat tolerance of United States Holsteins. Interbull Bull. 33:160-162.

Boonkum, W., I. Misztal, M. Duangjinda, V. Pattarajinda, S. Tumwasorn, and J. Sanpote. 2011. Genetic effects of heat stress on milk yield of Thai Holstein crossbreds. J. Dairy Sci. 94:487-492.

Bouraoui, R., M. Lahmar, A. Majdoub, M. Djemali, and R. Belyea. 2002. The relationship of temperature-humidity index with milk production of dairy cows in a Mediterranean climate. Anim. Res. 51:479-491.

Broucek, J., S. Ryba, S. Mihina, M. Uhrincat, and P. Kisac. 2007. Impact of thermal-humidity index on milk yield under conditions of different dairy management. J. Anim. Feed Sci. 16:329-344.

Brügemann, K., E. Gernand, U. U. von Borstel, and S. König. 2011. Genetic analyses of protein yield in dairy cows applying random regression models with time-dependent and temperature $\mathrm{x}$ humidity-dependent covariates. J. Dairy Sci. 94:4129-4139.

Dairyman. 2012. INTERREG IV project. Accessed Apr. 10, 2012. http://www.interregdairyman.eu/?id=142.

Dikmen, S., and P. J. Hansen. 2009. Is the temperature-humidity index the best indicator of heat stress in lactating dairy cows in a subtropical environment? J. Dairy Sci. 92:109-116.

Gantner, V., P. Mijić, K. Kuterovac, D. Solić, and R. Gantner. 2011. Temperature-humidity index values and their significance on the daily production of dairy cattle. Mljekarstvo 61:56-63.

Gaughan, J. B., T. L. Mader, S. M. Holt, and A. Lisle. 2008. A new heat load index for feedlot cattle. J. Anim. Sci. 86:226-234.

Godden, S., P. Rapnicki, S. Stewart, J. Fetrow, A. Johnson, R. Bey, and R. Farnsworth. 2003. Effectiveness of an internal teat seal in the prevention of new intramammary infections during the dry and early-lactation periods in dairy cows when used with a dry cow intramammary antibiotic. J. Dairy Sci. 86:3899-3911.

Igono, M. O., G. Bjotvedt, and H. T. Sanford-Crane. 1992. Environmental profile and critical temperature effects on milk production of Holstein cows in desert climate. Int. J. Biometeorol. 36:77-87.

Igono, M. O., H. D. Johnson, B. J. Steevens, W. A. Hainen, and M. D. Shanklin. 1988. Effect of season on milk temperature, milk growth hormone, prolactin and somatic cell counts of lactating cattle. Int. J. Biometeorol. 32:194-200. 
IPCC (Intergovernmental Panel on Climate Change). 2007. Climate Change 2007: The physical science basis. Contribution of working group I to the fourth assessment report of the intergovernmental panel on climate change. Cambridge University Press, Cambridge/ New York, NY.

Mader, T. L., M. S. Davis, and T. Brown-Brandl. 2006. Environmental factors influencing heat stress in feedlot cattle. J. Anim. Sci. 84:712-719.

Mader, T. L., L. J. Johnson, and J. B. Gaughan. 2010. A comprehensive index for assessing environmental stress in animals. J. Anim. Sci. 88:2153-2165.

Maróti-Agóts, Á., I. Bodó, L. Jávorka, A. Gyurmán, N. Solymosi, P. Zenke, M. Skogseth, and L. Zöldág. 2011. Possible genetic sign of heat stress adaptation in Hungarian Grey Bos taurus breed. Acta Biol. Hung. 62:65-72.

McDowell, L. R. 1976. Mineral deficiencies and toxicities and their effect on beef production in developing countries. Pages 216-241 in Beef Cattle in Developing Countries. A. J. Smith, ed. University of Edinburgh, UK.

Misztal, I., S. Tsuruta, T. Strabel, B. Auvery, T. Druet, and D. H. Lee. 2002. BLUPF90 and related programs (BGF90). Proc. 7th WCGALP. CD-ROM Commun. No. 28-07.

Moran, D. S., K. B. Pandolf, Y. Shapiro, Y. Heled, Y. Shani, W. T. Mathew, and R. R. Gonzalez. 2001. An environmental stress index (ESI) as a substitute for the wet bulb globe temperature (WBGT). J. Therm. Biol. 26:427-431.
NRC. 1971. A Guide to Environmental Research on Animals. Natl. Acad. Sci., Washington, DC.

Ravagnolo, O., and I. Misztal. 2000. Genetic component of heat stress in dairy cattle, parameter estimation. J. Dairy Sci. 83:2126-2130.

Reiczigel, J., N. Solymosi, L. Könyves, A. Maróti-Agóts, A. Kern, and J. Bartyik. 2009. Examination of heat stress caused milk production loss by the use of temperature-humidity indices. Magyar Állatorvosok Lapja 131:137-144.

Sánchez, J. P., I. Misztal, I. Aguilar, B. Zumbach, and R. Rekaya. 2009. Genetic determination of the onset of heat stress on daily milk production in the US Holstein cattle. J. Dairy Sci. 92:40354045 .

Shathele, M. S. 2009. Weather effect on bacterial mastitis in dairy cows. Int. J. Dairy Sci. 4:57-66.

Silva, R. G., D. A. E. F. Morais, and M. M. Guilhermino. 2007. Evaluation of thermal stress indexes for dairy cows in tropical regions. R. Bras. Zootec. 36:1192-1198.

St-Pierre, N. R., B. Cobanov, and G. Schnitkey. 2003. Economic losses from heat stress by US livestock industries. J. Dairy Sci. 86(E. Suppl.):E52-E77.

Thom, E. C. 1959. The discomfort index. Weatherwise 12:57-60.

Youssef, M. K. 1985. Stress Physiology in Livestock. CRC Press, Boca Raton, FL. 